\title{
Kelainan refraksi pada siswa SMP daerah pedesaan
}

\author{
${ }^{1}$ Indo Mamesah \\ ${ }^{2}$ Josefien S. M. Saerang \\ ${ }^{2}$ Laya M. Rares
}

\author{
${ }^{1}$ Kandidat Skripsi Fakultas Kedokteran Universitas Sam Ratulangi Manado \\ ${ }^{2}$ Bagian/SMF Ilmu Kesehatan Mata Fakultas Kedokteran Manado \\ Universitas Sam Ratulangi Manado \\ Email: indom3@gmail.com
}

\begin{abstract}
Visual impairment is defined as a functional limitation of the eye/eyes or visual system and can manifest in decreased visual acuity or contrast sensitivity, visual field loss, photophobia, visual distortion, visual perceptual difficulties, or a combination of them. Examination of the eye and vision assessment are very important to detect conditions that can cause blindness and serious systemic conditions, which cause problems in school performance, or at a more severe level, life threatening. This study aimed to obtain the occurence of refractive anomalies among junior high school students in rural areas. This was an analytical observational study with a cross-sectional design. The study was conducted in SMP I Wori (rural area) and SMP I Airmadidi (urban area). There were 60 respondents; 30 respondents of each school. Distributions of respondent genders were nearly the same for both schools; the number of females was higher than males. The majority of SMP I Airmadidi students were 11 years old (36.7\%), meanwhile the majority of SMP Wori students were 13 years (50\%). Most student complaints in SMP I Airmadidi were itchy eyes and drowsiness (16.7\%), meanwhile in SMP I Wori was headache (18.4\%). Visual impairment was found in $16.6 \%$ of students of SMP I Airmadidi, meanwhile in SMP I there was no student with refractive anomaly. Conclusion: There was no refractive anomaly found among students of rural area, however, among students of urban area myopia was the refractive anomaly found.
\end{abstract}

Keywords: refractive anomaly

\begin{abstract}
Abstrak: Gangguan penglihatan didefinisikan sebagai suatu keterbatasan fungsional pada mata atau kedua mata atau sistem visual yang dapat bermanifestasi terhadap penurunan ketajaman penglihatan atau sensitifitas kontras, hilangnya lapangan penglihatan, photofobia, distorsi visual, kesulitan perseptual visual atau kombinasi dari semua diatas. Pemeriksaan mata dan penilaian penglihatan sangat penting untuk mendeteksi kondisi yang dapat menyebabkan kebutaan dan kondisi sistemik serius, yang memicu masalah performa di sekolah, atau pada tingkat yang lebih berat, mengancam kehidupan anak. Penelitian ini bertujuan untuk mengetahui gambaran kelainan refraksi pada anak SMP di daerah pedesaan. Jenis penelitian ini analitik observasional dengan desain potong lintang. Penelitian dilakukan di SMPN I Wori (daerah luar Minahasa Utara/pedesaan) dan SMPN I Airmadidi (kota Kabupaten Minahasa Utara), dan diperoleh 60 responden penelitian. Distribusi jenis kelamin responden kedua sekolah hampir sama dimana jumlah perempuan lebih banyak dari laki-laki. Usia terbanyak di SMPN I Airmadidi ialah 11 tahun (36,7\%) sedangkan di SMPN Wori 13 tahun (50\%). Keluhan terbanyak siswa di SMPN I Airmadidi ialah mata gatal dan rasa kantuk (16,7\%), sedangkan di SMPN I Wori ialah sakit kepala (18, 4\%). Gangguan penglihatan ditemukan pada responden di SMPN I Airmadidi sebanyak 16,6 \% sedangkan di SMPN I tidak ditemukan kelainan visus. Simpulan: Tidak ditemukan adanya gangguan refraksi pada siswa SMP di daerah pedesaan. Kelainan refraksi miopia ditemukan pada siswa SMP di perkotaan.
\end{abstract}

Kata kunci: gangguan refraksi 
Gangguan penglihatan didefinisikan sebagai suatu keterbatasan fungsional pada mata atau kedua mata atau sistem visual dan dapat bermanifestasi terhadap penurunan ketajaman penglihatan atau sensitifitas kontras, hilangnya lapangan penglihatan, photofobia, distorsi visual, kesulitan perseptual visual atau kombinasi dari semua diatas. ${ }^{1}$

Pemeriksaan mata dan penilaian penglihatan sangat penting untuk mendeteksi kondisi yang dapat menyebabkan kebutaan, kondisi sistemik serius, yang memicu masalah dengan performa sekolah, atau pada tingkat yang lebih berat, mengancam kehidupan anak. Pengukuran ketajaman penglihatan dapat dilakukan pada umur sedini mungkin, dalam praktek biasanya dilakukan pada umur 3 tahun. Deteksi dini dan penanganan yang tepat terhadap gangguan ocular pada anak penting untuk menghindari gangguan visual permanen., ${ }^{2,3}$

Diperkirakan bahwa 2,3 miliar orang diseluruh dunia menderita gangguan refreksi. Kebanyakan dapat dikoreksi dengan kacamata, tapi hanya 1,8 miliar orang yang memiliki akses untuk pemeriksaan mata dan koreksi. Sekitar 500 juta orang kebanyakan di negara yang sedang berkembang, dan banyak anak, dengan gangguan penglihatan yang tidak dikoreksi menyebabkan kebutaan dan gangguan penglihatan. Kemampuan visual yang tidak dideteksi atau tidak dikoreksi dengan baik diketahui memengaruhi kemampuan belajar pada anak di sekolah, karena mereka sulit untuk membaca materi di papan tulis. Hal ini dapat memengaruhi pendidikan anak, pekerjaan dan status ekonomi dalam kehidupan mereka. ${ }^{1,4,5}$

Pada banyak kasus anak-anak dengan masalah penglihatan, dapat dideteksi dengan mudah melalui tes penglihatan sederhana (seperti skrining) dan dikoreksi tepat waktu dan penyesuaian yang tepat dari kacamata berkualitas (WHO, 2006). Namun, studi-studi yang dilakukan di negara-negara berkembang menunjukkan bahwa 35 sampai 85\% dari yang dengan gangguan refraksi tidak memiliki kacamata, dan beberapa dari mereka belum pernah menjalani skrining atau pemeriksaan. ${ }^{4}$

Negara berkembang seperti Indonesia, dengan cakupan wilayah yang sangat luas, ditambah jumlah penduduk miskin yang besar, akan mudah menemukan gangguan penglihatan diantara penduduk miskin. Menurut laporan Nasional Rikesdas (Riset Kesehatan Dasar, 2007), proporsi low vision di Indonesia sebesar 4,8\% dengan kisaran antara 1,7\% (di Provinsi Papua) hingga 10,1\% (di Provinsi Bengkulu), sedangkan Sulawesi Utara sebesar 3,4\% dengan kebutaan sebesar 0,5\%. Proporsi low vision dan kebutaan di Indonesia cenderung lebih tinggi pada perempuan dibandingkan dengan laki-laki, dan mungkin disebabkan oleh proporsi perempuan lebih tinggi daripada laki-laki. Proporsi low vision dan kebutaan di Indonesia berkaitan dengan tempat tinggal di daerah pedesaan dengan tingkat sosial ekonomi yang rendah. ${ }^{6}$

Minahasa Utara dengan jumlah Sekolah Menengah Pertama yang tersebar di 10 kecamatan yaitu 69 sekolah (negeri dan swasta), dengan jumlah siswa 7331 orang (2010). ${ }^{7}$

\section{METODE PENELITIAN}

Jenis penelitian ini ialah analitik observasional dengan desain potong lintang. Penelitian ini bertujuan untuk mengetahui gambaran kelainan refraksi pada anak SMP di daerah pedesaan terutama di Kecamatan Wori Kabupaten Minahasa Utara. Sampel diambil pada dua sekolah, yaitu SMPN I Wori dan SMPN I Airmadidi berjumlah 60 siswa.

\section{HASIL PENELITIAN DAN BAHASAN}

Penelitian ini dilakukan pada siswa SMP dan dipilih di daerah Minahasa Utara yang tingkat ekonomi sebagian besar penduduk masih cukup rendah, dibandingkan dengan daerah lain di Sulawesi Utara, walaupun terdapat beberapa bagian di daerah Minahasa Utara yang tingkat perekonomian penduduknya 
baik. Tingkat ekonomi yang rendah memengaruhi asupan komponen nutrisi yang penting untuk mata, sehingga insiden gangguan penglihatan lebih tinggi terdapat di negara-negara miskin atau negara yang sedang berkembang seperti Indonesia. Jadi dapat dianggap bahwa perbedaan tingkat ekonomi secara tidak langsung akan memengaruhi insiden gangguan refraksi.

Dari hasil penelitian pada 60 siswa diperoleh distribusi jenis kelamin responden kedua sekolah hampir sama dimana jumlah perempuan lebih banyak dari laki-laki dengan persentasi hampir sama. Usia usia terbanyak di SMPN I Airmadidi ialah 11 tahun (36,7\%), sedangkan di SMPN I Wori 13 tahun (50\%) Tabel 1).

Keluhan terbanyak siswa di SMPN I Airmadidi ialah mata gatal dan rasa kantuk (16,7\%), sedangkan di SMPN I Wori lah sakit kepala (18,4\%) (Tabel 2). Gangguangangguan seperti ini bisa dialami dan merupakan gejala awal gangguan visus yang mungkin terjadi di kemudian hari, sehingga gangguan ini dapat menjadi perhatian untuk mencegah gangguan mata berlanjut. $^{8}$

Tabel 1. Karakteristik sampel penelitian

\begin{tabular}{lcccc}
\hline \multirow{2}{*}{ Karakteristik sampel } & \multicolumn{2}{c}{ SMPN Airmadidi } & \multicolumn{2}{c}{ SMPN Wori } \\
\cline { 2 - 5 } & $\mathrm{n}$ & $\%$ & $\mathrm{n}$ & $\%$ \\
\hline Jenis kelamin & 6 & $20 \%$ & 7 & $23,3 \%$ \\
$\quad$ Laki-laki & 24 & $80 \%$ & 23 & $76,7 \%$ \\
$\quad$ Perempuan & 4 & $13,3 \%$ & 3 & $10 \%$ \\
\hline Usia & 11 & $36,7 \%$ & 11 & $36,7 \%$ \\
11 tahun & 9 & $30 \%$ & 15 & $50 \%$ \\
12 tahun & 6 & $20 \%$ & 1 & $3,3 \%$ \\
13 tahun & 6 & & & \\
\hline
\end{tabular}

Tabel 2. Karakteristik sampel berdasarkan gangguan mata

\begin{tabular}{clcccc}
\hline \multirow{2}{*}{ No } & Keluhan & \multicolumn{2}{c}{ SMPN } & \multicolumn{2}{c}{ SMPN Wori } \\
\cline { 3 - 6 } & & $\mathrm{n}$ & $\%$ & $\mathrm{n}$ & $\%$ \\
\hline 1 & Mata merah & 1 & 0,9 & 6 & 5,3 \\
2 & Sering keluar air mata sendiri saat membaca/nonton & 11 & 10,2 & 11 & 9,6 \\
3 & Mata terasa perih & 14 & 12,9 & 10 & 8,8 \\
4 & Mata terasa gatal & 18 & 16,7 & 16 & 14,0 \\
5 & Mata terasa kering & 3 & 2,8 & 4 & 3,5 \\
6 & Mata terasa mengantuk & 18 & 16,7 & 12 & 10,5 \\
7 & Mata terasa tegang & 10 & 9,3 & 9 & 7,9 \\
8 & Pelihatan seperti ada bayangan & 5 & 4,6 & 8 & 7,0 \\
9 & Penglihatan kabur & 7 & 6,5 & 0 & 0 \\
10 & Penglihatan rangkap & 2 & 1,8 & 1 & 0,9 \\
11 & Sulit melihat focus & 8 & 7,4 & 12 & 10,5 \\
12 & Sakit kepala & 10 & 9,3 & 21 & 18,4 \\
13 & Mual-mual bila lama membaca atau nonton & 1 & 0,9 & 4 & 3,5 \\
Jumlah & 108 & $100 \%$ & 114 & $100 \%$ \\
\hline
\end{tabular}

SMPN I Airmadidi merupakan daerah yang tingkat ekonomi lebih tinggi di
Kabupaten Minahasa Utara bila dibandingkan dengan Kecamatan Wori, 
sehingga pengaruh teknologi lebih dirasakan dan kemungkinan tingginya gangguan penglihatan pada sampel SMPN I Airmadidi lebih tinggi yaitu 6,16\%. Hasil ini lebih tinggi bila dibandingkan dengan penelitian Sirlan et al. (2009) di Jawa Barat dengan angka kelainan refrakasi sebesar 2,8\%, sedangkan penelitian Laonardo et al. yang dilakukan di Kecamatan Tallo Makasar (2010) menemukan angka 2,7\%. ${ }^{9}$

Gangguan penglihatan yang ditemukan pada sampel penelitian ini ialah gangguan penglihatan yang bisa ditangani atau dicegah berupa miopia (Tabel 3). Gangguan-gangguan ini berhubungan dengan perilaku yang salah. Gangguan penglihatan ditemukan pada sampel SMPN I Airmadidi yaitu 16,6\% sedangkan di SMPN I Wori tidak ditemukan kelainan visus. Hal ini menunjukkan bahwa perbedaan tingkat ekonomi pada penelitian ini tidak memengaruhi gangguan penglihatan pada sampel. Banyak faktor yang memengaruhi munculnya gangguan penglihatan pada anak. Kemajuan teknologi dalam dunia antara lain: internet dan, penggunaan smartphone yang menjamur, dapat meningkatkan terjadinya gangguan penglihatan pada anak.

Tabel 3. Karakteristik sampel berdasarkan gangguan visus

\begin{tabular}{lcccc}
\hline \multirow{2}{*}{ Visus } & \multicolumn{2}{c}{ SMPN Airmadidi } & \multicolumn{2}{c}{ SMPN Wori } \\
\cline { 2 - 5 } & $\mathrm{n}$ & $\%$ & $\mathrm{n}$ & $\%$ \\
\hline Normal & 25 & 83,3 & 30 & 100 \\
Miopia & 5 & 16,6 & 0 & 0 \\
Hipermetropia & 0 & 0 & 0 & 0 \\
astigmatisma & 0 & 0 & 0 & 0 \\
\hline
\end{tabular}

\section{SIMPULAN}

Dari hasil penelitian kelainan refraksi, tidak ditemukan adanya gangguan refraksi pada siswa SMP di daerah pedesaan (SMPN I Wori). Kelainan refraksi yang ditemukan pada siswa di daerah perkotaan (SMPN I Airmadidi) ialah miopia.

\section{SARAN}

1. Perlu dilakukan penelitian lanjutan dengan jumlah sampel yang lebih besar agar lebih mewakili jumlah populasi siswa SMP di Minahasa Utara.

2. Skrining berkala gangguan penglihatan pada siswa serta penyuluhan kesehatan mata perlu dilakukan mulai pada usia pra-sekolah untuk menghindari masalah penglihatan di kemudian hari.

\section{DAFTAR PUSTAKA}

1. Swanson J, Yasuda K, France I. Eye examination in infants, children, and young adults by pediatricians. Pediatrics. Official J Am Acad Pediatrics. 2008;111: 902-7.
2. Datta C, Bahrdwaj N, Patrikar S, Bhalwar C. Study of disorders of visual acuity among adolescent school children in Pune. MJAFI. 2009;65(1):26-9.

3. Fredman K, Cole RG, Freeman PB, et al. Care of the patient with visual impairment (Low vision rehabilitation). American Optometric Association, 2009; p. 11-9.

4. Maurya RP, Bushan PB, Singh VP, et al. Prevalence of oculo-visual disorders amongst university students in Varanasi District, North India. Pakistan Journal of Ophthalmology. 2012;28(2):86-9.

5. Goh PP, Abqariyah Y, Pokharel GP, Ellwein LB. Refractive error and visual impairment in school-age children in Gombak District, Malaysia. Opthalmology. 2005; 112:678-85.

6. BPPS Depkes. Riset kesehatan dasar 2007. Badan Penelitian dan Pengembangan Kesehatan. Jakarta: Departemen Kesehatan Republik Indonesia, 2008 
7. BPS Minahasa Utara, dalam angka. Badan Pusat Statistik Minahasa Utara, 2010.

8. Gary H. Refractive errors and refraction: How the eye sees. All about vision. 2010.

9. Muma MK, Kimani K, Kariuki MM,
Ilako DR, Njuguna MW. Prevalence of refractive errors among primary school pupils in Kilungu division of Makueni District, Kenya. Med J Zambia. 2009;36(4):165-9. 